\title{
Performance and feed efficiency of beef cattle fed high energy diet with probiotic consortium technology
}

Desempenho e eficiência alimentar de bovinos de corte alimentados com dieta de alto nível energético recebendo a tecnologia do consórcio probiótico

MOREIRA, Gabriel Miranda ${ }^{1 *}$, MENESES, Javier Andrés Moreno ${ }^{1}$, RIBEIRO, Cintia Vanin ${ }^{2}$, FARIA, Alyce de Melo ${ }^{1}$, ARANTES, Helena Graciani ${ }^{1}$, LUZ, Matheus Henrique da ${ }^{1}$, AURELIANO, Rafaella ${ }^{1}$, MONTEIRO, Maria Gabriela Borges Bahia ${ }^{1}$, GOMES, Amanda Desenzi $^{1}$, FERREIRA, Pedro Henrique ${ }^{1}$, SIQUEIRA, Ariane Maria Almeida ${ }^{2}$, Mateus Pies GIONBELLI $^{1}$

${ }^{1}$ Universidade Federal de Lavras, Departamento de Zootecnia, Lavras, Minas Gerais, Brasil

${ }^{2}$ Universidade Federal de Lavras, Departamento de Medicina Veterinária, Lavras, Minas Gerais, Brasil

*Endereço para correspondência: gmmzootecnia@gmail.com

ORCID ID

https://orcid.org/0000-0001-8974-6885

\section{SUMMARY}

The objective of this study was to evaluate the effect of probiotic consortium on feed intake, feeding behavior, feed efficiency, fecal score, weight gain and carcass traits in finishing Nellore heifers fed high energy diets in feedlot. Twenty-four Nellore heifers were distributed in 12 pens with two animals each, being six pens per treatment. In the control treatment $(\mathrm{CON})$ the animals were fed exclusively with the base diet, which contained $35 \%$ corn silage and $65 \%$ concentrate. In the treatment with probiotic consortium technology (TCP), the animals received the base diet and a single dose of $75 \mathrm{~mL} / \mathrm{animal} / \mathrm{day}$ of Bio Ciclo Completo (Global Saúde Brasil) top-dressed in the morning feeding. There was no period of adaptation to the diet. The experiment lasted 93 days. The use of TCP did not affect $(\mathrm{P}=0.980)$ the dry matter intake. The average daily gain was $12.5 \%$ greater $(\mathrm{P}=$ $0.025)$ in the animals treated with TCP $(0.941 \mathrm{~kg} /$ day for TCP versus $0.834 \mathrm{~kg}$ /day for CON). The animals that received TCP improved $(\mathrm{P}=0.021)$ the feed efficiency by $12.6 \%$. The animals that received TCP tended to have a better $(P=0.094)$ fecal score within the first 27 days of feedlot. There were no significant effects of TCP on the feeding behavior and carcass traits. Based on the results, there is a great potential of using TCP to improve productivity in beef cattle.

Keywords: Average daily gain, dry matter intake, fecal score, feedlot finishing

\section{RESUMO}

O objetivo desse trabalho foi avaliar o efeito do consórcio probiótico sobre consumo de alimento, comportamento alimentar, eficiência alimentar, escore fecal, ganho de peso e características de carcaça na terminação em confinamento de novilhas Nelore alimentadas com dieta de alta energia. Vinte e quatro novilhas da raça Nelore foram distribuídas em 12 baias com dois animais cada, sendo seis baias para cada tratamento. A dieta base continha $35 \%$ de silagem de milho e $65 \%$ de concentrado. No tratamento controle $(\mathrm{CON})$ os animais foram alimentados exclusivamente com a dieta base. No tratamento com tecnologia de consórcio probiótico (TCP), os animais receberam, além da dieta base, uma dose única de $75 \mathrm{~mL} /$ animal/dia de Bio Ciclo Completo (Global Saúde Brasil) sobre a ração na alimentação matinal. Nenhum período de adaptação à dieta foi realizado. $\mathrm{O}$ período experimental durou 93 dias. $\mathrm{O}$ uso de TCP não alterou $(P=0,980)$ o consumo de matéria seca em relação ao CON. O ganho médio diário foi $12,5 \%$ maior $(\mathrm{P}=0,025)$ nos animais tratados com 
TCP $(0,941 \mathrm{~kg} /$ dia para TCP versus 0,834 $\mathrm{kg} /$ dia para CON). Os animais que receberam TCP melhoraram $(\mathrm{P}=0,021)$ a eficiência alimentar em $12,6 \%$. Os animais que receberam TCP tenderam a ter melhor $(\mathrm{P}=0,094)$ escore fecal nos primeiros 27 dias de confinamento. Não houve efeitos significativos da TCP sobre o comportamento alimentar e características de carcaça. Com base nos resultados observados nesse estudo, existe um grande potencial de utilização do TCP para melhorar a produtividade em bovinos de corte.

Palavras-chave: Consumo de matéria seca, escore fecal, ganho médio diário, terminação em confinamento. 


\section{INTRODUCTION}

Manipulating the ruminal microbial ecosystem to maximize production efficiency by ruminants has been a challenge to nutritionists and rumen microbiologist

(NAGARAJA \&TAYLOR, 1987). Several attempts have been made to optimize ruminal fermentation using antibiotics (propionate enhancers). Ionophores antibiotics alter fermentation characteristics, resulting in favorable metabolic changes in the rumen. Energy metabolism efficiency is improved by altering the types of volatile fatty acids produced in the rumen (increase of propionate, reduction of acetate and butyrate) and energy loss decreases during food fermentation (BERGEN \& BATES, 1984).

Public and scientific concern about the use of antibiotics as feed additives in animal production has increased(GAGGİA et al., 2010). According to Jouany \&Morgavi (2007), the main reasons for this concern are the emergence of antibiotic resistance in many human pathogenic bacteria, the release of contaminating residues into the environment and the risk that growth-promoting antibiotic residues may occur in foods of animal origin. For these reasons, there is a growing demand for more affordable and safer alternatives which can improve the defense mechanisms of food-production animals, reduce the requirement for antibiotics, and increase overall net profits of livestock-raising facilities(STOVER et al., 2016).

Feeding probiotics are one alternative that has shown benefit to cattle production (KREHBIEL et al., 2003; SEO et al., 2010). Fuller (1989) defined probiotics as 'live microbial feed supplements which beneficially affect the host animal by improving its microbial balance'. Probiotics have the ability to enhance intestinal health by stimulating the development of a healthy microbiota, preventing enteric pathogens from colonizing the intestine, increasing digestive capacity, lowering $\mathrm{pH}$ and improving mucosal immunity(UYENO et al., 2015). The use of probiotics is a good tool to balance the ruminal environment since the finishing of beef cattle in feedlot usually offers diets with high content of readily fermentable carbohydrates that increases the risk of acidosis(JOUANY \& MORGAVI, 2007).

The preparation of probiotics may consist of a single strain or of a mixture of different strains(VIBHUTE et al., 2011). The probiotic consortium technology consists of balanced populations of different probiotic strains trained to live together via growth selection. Products from this technology have been used in Europe for some years (CHAUCHEYRAS-DURAND et al., 2008). However, in Brazil, there is no marketable product containing the use of such technology.

We hypothesized that probiotic consortium reduces daily ingestion variations, reflecting in improved performance and carcass characteristics of beef cattle in feedlot. The objective of this study was to evaluate the effect of probiotic consortium on feed intake, feeding behavior, feed efficiency, fecal score, weight gain and carcass traits in finishing feedlot Nellore heifers fed high energy diets. 


\section{MATERIALS AND METHODS}

The study was performed at the beef cattle facilities of the Department of Animal Science (DZO) of the Federal University of Lavras (UFLA), Minas Gerais, Brazil. The project was approved by the ethics committee on the use of animals- UFLA under the protocol number 043/2017.

Twenty-four Nellore heifers were identified, weighed, treated against endo and ectoparasites and housed in pasture until the beginning of the experiment. The experiment was carried out in a completely randomized design with the initial body weight (into the feedlot) as a covariate. The animals were distributed in 12 pens with two animals each. The initial average body weight was $256.1 \pm 28.2 \mathrm{~kg}$ and initial average age was 18 months. The area of the pens was $25 \mathrm{~m}^{2}$ with $6 \mathrm{~m}^{2}$ of shade and concrete floor in front of the feed bunk.

The experimental diet contained $35 \%$ of roughage and $65 \%$ of concentrate, representing the average diet used in beef cattle feedlots in Brazil (Table 1). The feeding was performed twice a day (8 a.m. and 4 p.m.). The pens were randomly assigned to one of the two treatments. In the control treatment (CON) the animals were fed exclusively with the base diet described in Table 1 . In the treatment with probiotic consortium technology (TCP), the animals received the base diet and a single dose of $75 \mathrm{~mL} / \mathrm{animal} / \mathrm{day}$ of Bio Ciclo Completo (Global Saúde Brasil)top-dressed in the morning feeding. The product consists of lactic acid bacteria $\left(>3,0 \times 10^{5} \mathrm{cfu} / \mathrm{mL}\right)$ and yeasts $\left(<1,0 \times 10^{6} \mathrm{cfu} / \mathrm{mL}\right)$. There was no period of adaptation to the diets because the probiotic consortium is supposed to assist in the faster adaptation of cattle to diets with a higher energy level.

The experimental period lasted 93 days and was divided into three phases: phase $1=0$ to 27 days; phase $2=28$ to 58 days; phase $3=59$ to 93 days. The animals were weighed individually at the end of each phase to determine weight gain. Feeds as well as leftovers were weighed and sampled daily to calculate the dry matter intake and feed efficiency ( $\mathrm{kg}$ gain per $\mathrm{kg}$ of feed ingested) in each of the three phases of the feedlot.

Table 1. Composition of the base diet used in the experiment

\begin{tabular}{lc}
\hline Ingredients & Inclusion in diet $(\% \mathrm{DM})$ \\
\hline Corn silage & 35.00 \\
Corn grain & 58.01 \\
Soybean meal & 4.23 \\
Urea & 0.76 \\
Mineral premix ${ }^{1}$ & 2.00 \\
\hline Nutritional fraction & $\%$ of diet $(\mathrm{DM})$ \\
\hline Crude protein & 12.00 \\
Total digestible nutrients ${ }^{2}$ & 74.52 \\
\hline${ }^{1}$ Composition: calcium $=10 \% ;$ phosphorus $=4 \% ;$ sodium $=16,5 \% ;$ sulfur $=6,000 \mathrm{mg} / \mathrm{kg} ;$ \\
magnesium $=5,000 \mathrm{mg} / \mathrm{kg} ;$ copper $=680 \mathrm{mg} / \mathrm{kg} ;$ zinc $=2,580 \mathrm{mg} / \mathrm{kg} ;$ fluorine $=400 \mathrm{mg} / \mathrm{kg} ;$ \\
manganese $=750 \mathrm{mg} / \mathrm{kg}$; iron $350 \mathrm{mg} / \mathrm{kg} ;$ selenium $=7 \mathrm{mg} / \mathrm{kg} ;$ iodine $=45 \mathrm{mg} / \mathrm{kg} ;$ cobalt $=35$ \\
mg $/ \mathrm{kg} .{ }^{2}$ Calculated according Cappelle et al. $(2001)$.
\end{tabular}


Feces were scored once week (before the morning feeding) by the same two trained evaluators. The score was based on the physical shape and consistency of the three freshest feces in the pens according to the procedure described by Litherl and (2007): 1= watery, loose, diarrheic; $2=$ pasty, spreads around 20 centimeters, does not form concentric circles; $3=$ ideal, feces of pasty consistency, when falling forms concentric circles not very pronounced; $4=$ firm consistency, when falling has a conical shape, has no depressions in the center; and $5=$ hard consistency, concentric rings very pronounced and interconnected.

In the last week of each period of confinement, an evaluation of the feeding behavior of the animals was performed. A continuous evaluation was carried out for 72 hours with the identification of the activities (feeding, standing rumination, lying rumination, water intake, locomotion, standing idleness, and lying idleness) of each animal in ten minutes intervals.

At the 85th day of experiment, carcass images were collected by ultrasound (model SSD 500v,Aloka)equipped with a $17.2 \mathrm{~cm}, 3.5 \mathrm{MHz}$ linear transducer. Carcass images were obtained from the left side of the animal for evaluation of subcutaneous fat thickness between the 12th and 13th ribs, $3 / 4$ the length ventrally over the longissimus muscle and rump fat thickness at the junction of the biceps femoris and gluteus medius between the ischium and illium and parallel to the vertebral column. To ensure proper contact between the ultrasound transducer and animal, the transducer was fitted with a Superflab guide for subcutaneous fat thickness image collection. Vegetable oil was used as a couplant to obtain adequate acoustic contact. Once a suitable image had been obtained, the image was digitized and stored on a personal computer with a video frame grabber. Only one image per animal was stored for each ultrasound trait. Images were analysed in the Bio Soft Toolbox ${ }^{\circledR}$ II for Beef software (Biotronics Inc., Ames, IA, USA).

Diet and leftover samples were collected multiple times per week throughout the experiment. Samples were composited weekly and sent for analysis in the Animal Research Laboratory (LPA) of DZO/UFLA. The composited offer and orts of each pen were utilized to determine dry matter (INCT-CA G-003/1), organic matter determined by ash (INCT-CA M001/1), crude protein (INCT-CA N001/1), neutral detergent fiber (INCTCA F-002/1), acid detergent fiber(INCTCA F-004/1), and ether extract(INCTCA G-005/1) according Detmann et al.(2012). The value of total digestible nutrients was predicted according Cappelle et al. (2001) from the neutral detergent fiber composition of the diet using the equation $\mathrm{TDN}=91,0246-$ $(0,571588 * \mathrm{NDF})$.

The experiment was carried out in a completely randomized design with initial body weight (into the feedlot) as a covariate. Statistical analyzes were performed using the GLM procedure of SAS Software, version 9.2, considering $0.05 \%$ as the critical level of probability for occurrence of Type I error and between 0.05 and 0.10 as a trend. The statistical model used for the analysis of the data was $\mathrm{Y}=\mu+\mathrm{P}+\varepsilon_{\mathrm{ij}}$, where $\mathrm{Y}=$ response variable, $\mu=$ general mean, $\mathrm{P}$ $=$ fixed effect of the treatment $(\mathrm{CON}$ or $\mathrm{TCP}$ ), and $\varepsilon_{\mathrm{ij}}=$ unobservable random error.

\section{RESULTS AND DISCUSSION}

The results of average daily dry matter intake (DMI) per animal and intake per 
unit of live weight are presented in Table 2. In general, the use of TCP did not affect the intake level $(\mathrm{P}=0.980$ and $\mathrm{P}=0.756$, respectively). The level of DMI observed in this experiment is aligned with the level expected for zebu cattle confined under tropical conditions(AZEVÊDO et al., 2016). The lack of effect on intake in response to probiotic supplementation was also observed by other authors (GHORBANI et al., 2002; KEYSER et al., 2007; KELSEY \& COLPOYS, 2018)

Weights and daily average gain in each phase and total are presented in Table 2. No statistical differences were observed for the effect of treatments on the weights performed over the experimental period. However, animals treated with TCP presented $12.5 \%$ more in average daily gain $(\mathrm{P}=0.025)$. When considering only the period from 28 to 93 days (phases 2 and 3, without the initial 27 days, which would correspond to an adaptation period), the performance of the animals fed with TCPt ended to be higher $(\mathrm{P}=0.078)$ than the animals in the control group. During these phases, the animals that received TCP had an additional individual gain of $14.6 \mathrm{~kg}$ (in 66 days), which represented an improvement of $13 \%$ in the average daily gain.

The values of average daily gains below $1 \mathrm{~kg} /$ day are related to the fact that the experiment was performed with animals that came from good nutritional conditions in the pasture, receiving energetic protein supplementation. Thus, compensatory gain, which occurs when animals enter the feedlot after passing feed restriction period in the pasture, was purposely avoided. Under compensatory gain conditions, the pure effects of TCP usage could be masked. Thus, once it has been ensured that there is no compensatory effect in this experiment, it can be said that the results observed for the use of TCP in relation to the control treatment are free of confounding effects.

Another result that corroborates the lack of compensatory gain in this study is the lower weight gain of the animals in the initial phase of feedlot (first 4 weeks). At this stage, it is observed that the animals went through a period of adaptation to the feedlot diet. No adverse effects, such as clinical acidosis, were observed. However, it is possible that TCP controlled some of the possible occurrence of subclinical acidosis (not identified with the naked eye) during this phase, also contributing to the improvement of their performance.

Since they did not show any changes in DMI in relation to the animals fed with the control diet, and presented better performance, the animals that received TCP also had better feed efficiency $(\mathrm{P}=$ 0.021 , Table 2). It is observed that the use of TCP improved the feed conversion of feed into product by $12.6 \%$. Kelsey \& Colpoys (2018) used a probiotic containing strains of Enterococcus faecium, Lactobacillus acidophilus, Lactobacillus casei, and Lactobacillus plantarum and found that weaned calves receiving dietary probiotics had greater ADG and feed efficiency compared with those that did not receive probiotics. Improved performance may be partially explained by the probiotics benefits of increasing feed digestibility, preventing excess of lactate production and improving ruminal fermentation (SEO et al., 2010). 
Table 2. Intake, weight gain and feed efficiency of Nellore heifers fed with diet containing probiotic consortium technology (TCP) compared to a control $(\mathrm{CON})$ treatment

\begin{tabular}{lcccc}
\hline \multirow{2}{*}{ Item } & \multicolumn{2}{c}{ Treatment } & \multirow{2}{*}{ SEM $^{2}$} & \multirow{2}{*}{ P-value } \\
\cline { 2 - 3 } & CON & TCP $^{1}$ & & \\
Dry matter intake (DMI) & 7.55 & 7.54 & 0.359 & 0.980 \\
DMI, kg/day & 25.5 & 25.3 & 0.422 & 0.756 \\
DMI, g/day/BW & & & & \\
Weights & 257.5 & 255.7 & 12.2 & 0.874 \\
Initial body weight, kg & 269.1 & 267.6 & 11.8 & 0.932 \\
Weight at 27 days, kg & 304.4 & 307.7 & 13.5 & 0.865 \\
Weight at 58 days, kg & 335.0 & 342.2 & 13.5 & 0.726 \\
Weight at 93 days, kg & & & & \\
Average daily gain (ADG) & 0.431 & 0.480 & 0.068 & 0.620 \\
Phase $1^{4}, \mathrm{~kg} /$ day & 1.138 & 1.239 & 0.087 & 0.237 \\
Phase 2 ${ }^{5}, \mathrm{~kg} /$ day & 0.876 & 0.986 & 0.044 & 0.108 \\
Phase 36, kg/day & 0.999 & 1.130 & 0.047 & 0.078 \\
Phase 2 and 3, kg/day & 0.834 & 0.941 & 0.029 & 0.025 \\
Total, kg/day & 0.111 & 0.125 & 0.004 & 0.021 \\
Feed efficiency ratio (ADG:DMI) & & & & \\
\hline
\end{tabular}

${ }^{1}$ Probiotic consortium technology $(75 \mathrm{~mL} / \mathrm{animal} /$ day $) .{ }^{2}$ Standard error of the mean. ${ }^{3}$ Body weight $(\mathrm{kg}) .^{4} 0$ to 27 days. ${ }^{5} 28$ to 58 days. ${ }^{6} 59$ to 93 days.

Animals receiving TCP had no increase in DMI at the initial stages of feedlot (a fact that could represent an improvement in dietary adaptation; Figure 2). This means that improved performance and feed efficiency with the use of TCP is hardly related to the stabilization in DMI. When evaluating the individual variation (in each pen) of DMI during the weeks of feedlot through the coefficient of variation $(\%)$ between one week and another, no differences were observed between pens of TCP or control (Figure 1). Animals that present more stable DMI, with lower daily variations in the levels of intake, are those that present better performance in the feedlot, probably due to the lower incidence of subclinical acidosis and better feed use. Thus, they manage to maintain a more stable ruminal environment, as well as the flow of feed and by-products of ruminal fermentation (volatile fatty acids). However, inferences about the effect of TCP on the ruminal environment cannot be performed from this study. For this, a study with rumen-cannulated animals would be necessary. 


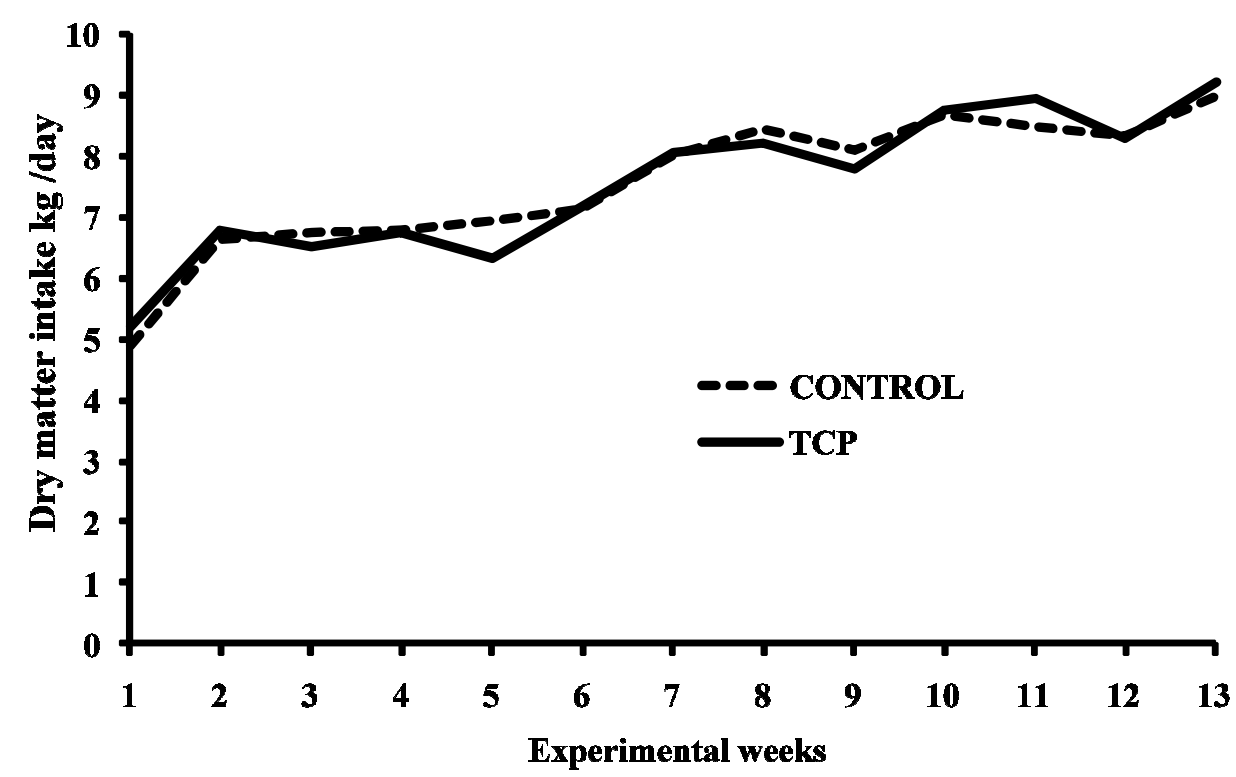

Figure 1. Weekly evolution of dry matter intake of Nellore heifers fed with diet containing probiotic consortium technology (TCP) compared to a control (CON) treatment

Fecal scores of heifers with or without TCP are shown in Table 3 and Figure 2. The fecal score was evaluated weekly and indicates the intestinal health of animals. When rumen function is impaired in terms of rumination, bacterial breakdown, and passage leads to the alteration in fecal aspects(HERNÁNDEZ et al., 2014). Animals that received TCPt ended to have a better fecal score (closer to 3 , which represents the ideal score) in the first four weeks of feedlot $(\mathrm{P}=0.094)$. This fact may indicate a better adaptation of the gastrointestinal flora of the animals that received TCP in the initial feedlot periods. Although the difference is not extremely large (8\%), this fact may partly contribute to better feed efficiency and performance of animals receiving TCP.

In the other feedlot periods (intermediate and final phase), there were no significant effects of TCP on the fecal score. There were no significant effects of TCP on the feeding behavior of animals (Table 4), indicating that the increase in feed efficiency may be related to other factors not related to feeding time, rumination time and water intake. It may be related to the type of diet.

The use of TCP did not change the leisure and walking times of the animals. Although no differences were observed in the behavior of the animals, it does not mean that TCP is not able to improve animal welfare and behavior under other conditions. In this study, the animals were in ideal conditions (no stress, good diet, adequate environment, disease free, etc.). 
Table 3.Fecal score of Nellore heifers fed with diet containing probiotic consortium technology (TCP) compared to a control (CON) treatment

\begin{tabular}{|c|c|c|c|c|}
\hline \multirow{2}{*}{ Item } & \multicolumn{2}{|c|}{ Treatment } & \multirow{2}{*}{$\mathrm{SEM}^{2}$} & \multirow{2}{*}{ P-value } \\
\hline & $\mathrm{CON}$ & $\mathrm{TCP}^{1}$ & & \\
\hline Phase $1^{3}$ & 2.71 & 2.93 & 0.084 & 0.094 \\
\hline Phase $2^{4}$ & 3.06 & 3.10 & 0.083 & 0.752 \\
\hline Phase $3^{5}$ & 3.73 & 3.82 & 0.092 & 0.484 \\
\hline Average fecal score & 3.22 & 3.31 & 0.068 & 0.357 \\
\hline
\end{tabular}

${ }^{1}$ Probiotic consortium technology $\left(75 \mathrm{~mL} /\right.$ animal/day). ${ }^{2}$ Standard error of the mean. ${ }^{3} 0$ to 27 days. ${ }^{4} 28$ to 58 days. ${ }^{5} 59$ to 93 days.

In unbalanced systems or with some stressful factors, it is hypothesized that TCP can improve the behavior of the animals by improving a series of productive characteristics, mainly related to the improvement of the ruminal environment. In a study with male Nellore cattle, approximately 18 months old, fed Brachiaria brizantha under a rotational grazing system, the animals fed probiotics for 150 days had lower cortisol concentrations compared with those which did not receive probiotics (PENHA et al., 2011).

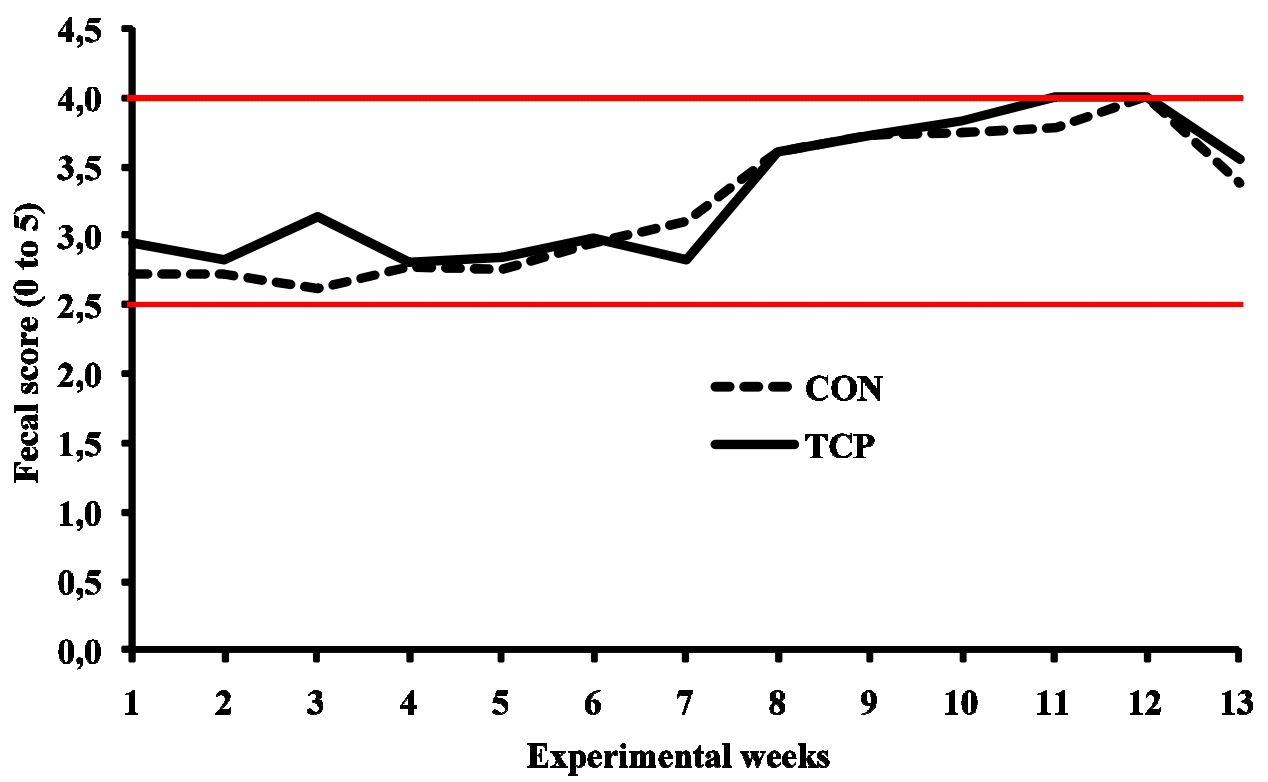

Figure 2 . Weekly evolution of fecal score ( $0=$ watery to $5=$ hard consistency) of Nellore heifers fed with diet containing probiotic consortium technology (TCP) compared to a control $(\mathrm{CON})$ treatment. The red lines represent the ideal range in which the average fecal score of the pens should be positioned. 
Table 4.Feeding behavior of Nellore heifers fed with diet containing probiótico consortium technology (TCP) compared to a control (CON) treatment

\begin{tabular}{|c|c|c|c|c|}
\hline \multirow{2}{*}{ Activity (minutes/day) } & \multicolumn{2}{|c|}{ Treatment } & \multirow{2}{*}{$\mathrm{SEM}^{2}$} & \multirow{2}{*}{ P-value } \\
\hline & $\mathrm{CON}$ & $\mathrm{TCP}^{1}$ & & \\
\hline Feeding & 159.0 & 163.0 & 6.92 & 0.686 \\
\hline Total rumination & 314.0 & 314.0 & 9.13 & 0.974 \\
\hline Standing rumination & 38.8 & 38.8 & 4.89 & 0.995 \\
\hline Lying rumination & 275.0 & 275.0 & 10.23 & 0.979 \\
\hline Total chewing activities ${ }^{3}$ & 473.0 & 478.0 & 11.58 & 0.789 \\
\hline Water intake & 11.5 & 9.2 & 0.96 & 0.128 \\
\hline Locomotion & 25.2 & 27.2 & 5.68 & 0.813 \\
\hline Total idleness & 930.0 & 926.0 & 12.86 & 0.822 \\
\hline Standing idleness & 360.0 & 351.0 & 13.17 & 0.672 \\
\hline Lying idleness & 570.0 & 574.0 & 17.82 & 0.878 \\
\hline
\end{tabular}

${ }^{1}$ Probiotic consortium technology $\left(75 \mathrm{~mL} /\right.$ animal/day). ${ }^{2}$ Standard error of the mean. ${ }^{3}$ Feedingplus rumination.

The results of the carcass traits evaluated by ultrasonography are presented in Table 5. No significant effects of TCP on the carcass traits were observed ( $\mathrm{P} \geq 0.39 ; \mathrm{P} \geq 0.58)$. This agrees with Krehbiel et al., 2003; Peterson et al., 2007; Vasconcelos et al., 2008; Scott et al., 2017, who did not find changes on carcass traits with the addition of probiotic to diet of beef cattle. Although not statistically different, heifers fed diet supplemented with TCP were numerically superior in subcutaneous and rump fat thickness (11\% and $8 \%$, respectively). Larger trials with a greater number of animals and slaughtering of these animals could help in the investigative process of the effect of TCP on the carcass composition.

Table 5. Carcass traits evaluated by ultrasonography in Nellore heifers fed with diet containing Probiotic Consortium Technology (TCP) compared to a control $(\mathrm{CON})$ treatment

\begin{tabular}{|c|c|c|c|c|}
\hline \multirow[b]{2}{*}{ Item } & \multicolumn{2}{|c|}{ Treatment } & \multirow{2}{*}{$\mathrm{SEM}^{2}$} & \multirow[b]{2}{*}{ P-value } \\
\hline & $\mathrm{CON}$ & $\mathrm{TCP}^{1}$ & & \\
\hline Subcutaneous fat thickness, $\mathrm{mm}$ & 4.80 & 5.36 & 0.44 & 0.391 \\
\hline Rump fat thickness, mm & 3.30 & 3.57 & 0.33 & 0.584 \\
\hline
\end{tabular}

${ }^{1}$ Probiotic consortium technology ( $75 \mathrm{~mL} / \mathrm{animal} /$ day $) .{ }^{2}$ Standard error of the mean.

In Table 6 we can observe an individual economic evaluation of the use of TCP compared to control treatment. The TCP treatment increased the daily cost per animal by $10.5 \%$. On the other hand, we observe that the animals in the TCP treatment showed an increased carcass daily gain by $12.8 \%$. As a result, an increase of $56.0 \%$ or $\mathrm{R} \$ 0.11$ was observed in the daily gross profit per confined heifer receiving TCP, demonstrating the positive effect of this treatment. These values can be considered significant when extrapolated to commercial feedlot conditions. Similarly, other authors (ARENAS et al., 2007;ALVES et al., 2004;JORGEet al., 2006), working with 
animals receiving probiotic supplementation, found a significant

increase in daily weight gain and gross profit per animal.

Table 6. Individual economic evaluation of the use of probiotic consortium technology (TCP) compared to a control (CON) treatment to Nellore heifers on feedlot

\begin{tabular}{|c|c|c|}
\hline \multirow{2}{*}{ Item } & \multicolumn{2}{|c|}{ Treatment } \\
\hline & $\mathrm{CON}$ & $\mathrm{TCP}^{1}$ \\
\hline Daily base diet cost, $\mathrm{R} \$$ & 3.71 & 3.71 \\
\hline Daily operational cost, $\mathrm{R} \$$ & 0.35 & 0.35 \\
\hline Daily treatment cost, $\mathrm{R} \$$ & - & 0.43 \\
\hline Daily total $\operatorname{cost}^{2}, \mathrm{R} \$$ & 4.06 & 4.49 \\
\hline Carcass daily gain ${ }^{3}$, @ & 0.030 & 0.034 \\
\hline Arroba value, R\$/@ & 140.00 & 140.00 \\
\hline Daily gross revenue ${ }^{4}, \mathrm{R} \$$ & 4.20 & 4.74 \\
\hline Daily gross profit, $\mathrm{R} \$$ & 0.14 & 0.25 \\
\hline
\end{tabular}

${ }^{1}$ Probiotic consortium technology $\left(75 \mathrm{~mL} /\right.$ animal/day). ${ }^{2}$ Daily base diet cost + daily operational cost + daily treatment cost. ${ }^{3}$ Considering $54 \%$ of dressing percentage.

From these results, it was concluded that there is a great potential of using probiotic consortium technology to improve productivity in beef cattle. We highlight the improvement in feed efficiency that led to better performance

\section{REFERENCES}

ALVES, J.B.; ISEPON, O.J.; BERGAMASHINE, E. A.F. Efeitos de aditivo alimentar enzimático contendo probiótico no desempenho de bovinos Guzerá em confinamento. In: 41a Reunião Anual da Sociedade Brasileira de Zootecnia, 2004, Campo Grande. Campo Grande. Anais... Sociedade Brasileira de Zootecnia, p.1-6. 2004.

ARENAS, S.E.; REIS, L.S.; FRAZATTI-GALLINA,N.M.; GIUFFRIDA,R.; PARDO, P.E. Effect of probiotic Proenzime ${ }^{\circledR}$ on weight gain in cattle. Archivos de Zootecnia, vol. 56, n. 213, p. 76.2007.

AZEVÊDO, J. A. G.; VALADARES FILHO, S. de C.; COSTA E SILVA, L. F.; SANTOS, A. B. dos; SOUZA, L. L.; of the animals receiving TCP and higher daily gross profits per animal. However, further research should be carried out to elucidate the mechanisms that allow the product to improve cattle performance.

ROTTA, P. P.; RENNÓ, L. N.;

PRADO, I. N. do. Regulação e predição de consumo de matéria seca. In: VALADARES FILHO, S. de C et al. Exigências Nutricionais de Zebuínos Puros e Cruzados - BR CORTE, p. 15-43, 2016.

BERGEN, W. G.; BATES, O. B. lonophores: their effect on production efficiency and mod e of action. Journal of Animal Science, Champaign, v. 58, n. 6, p. 1465-1483, 1984.

CAPPELLE, E. R., VALADARES FILHO, S. DE C., SILVA, J. F. C. DA, $\&$ CECON, P. R. Estimativas do Valor Energético a partir de Características Químicas e Bromatológicas dos Alimentos. Revista Brasileira de Zootecnia, v. 30, n. 6, p. 1837-1856, 2001. 
CHAUCHEYRAS-DURAND, F.; WALKER, N. D.; BACH, A. Effects of active dry yeasts on the rumen microbial ecosystem: Past, present and future. Animal Feed Science and Technology, v. 145, n. 1-4, p. 5-26, 2008.

DETMANN, E.; SOUZA, M. A.; VALADARES FILHO, S. de C.; QUEIROZ, A. C.; BERCHIELLI, T. T.; SALIBA, E. O. S.; CABRAL, L. S.; PINA, D. S.; LADEIRA, M. M.; AZEVÊDO, J. A. G. (Eds.) Métodos para análise de alimentos. Visconde do Rio Branco, MG: Suprema, 214p., 2012.

FULLER, R. Probiotics in man and animals. Journal of Applied

Bacteriology, v. 66, n. 5, p. 365-378, 1989.

GAGGİA, F.; MATTARELLI, P.; BIAVATI, B. Probiotics and prebiotics in animal feeding for safe food production. International Journal of Food Microbiology, v. 141, n. SUPPL., p. S15-S28, 2010.

GHORBANI, G. R.; MORGAVI, D. P.; BEAUCHEMIN, K. A.; LEEDLE, J. A. Z. Effects of bacterial direct-fed microbials on ruminal fermentation, blood variables, and the microbial populations of feedlot cattle. Journal of Animal Science, v. 80, n. 7, p. 19771985, 2002.

HERNÁNDEZ, J.; BENEDITO, J. L.; ABUELO, A.; CASTILLO, C. Ruminal acidosis in feedlot: From aetiology to prevention. Scientific World Journal, v. 2014, 2014.

JORGE, C.F.; ROSA, G.O.; SILVA, I.S.; VARGAS, F.M.; ARIAS, R.A. Efeito de um aditivo alimentar contendo probiótico e enzimas digestivas no ganho de peso de bovinos nelore em regime de pasto. In: IV Encontro de Pesquisa e Iniciação Científica do Estado e da Região do Pantanal, Campo Grande, Brasil. Anais... Campo Grande, Universidade para o Desenvolvimento do Estado e da Região do Pantanal, p.69-79. 2006.

JOUANY, J. P.; MORGAVI, D. P. Use of "natural" products as alternatives to antibiotic feed additives in ruminant production. Animal, v. 1, n. 10, p. 1443-1466, 2007.

KELSEY, A. J.; COLPOYS, J. D. Effects of dietary probiotics on beef cattle performance and stress. Journal of Veterinary Behavior, v. 27, p. 8-14, 2018.

KEYSER, S. A.; MCMENIMAN, J. P.; SMITH, D. R.; MACDONALD, J. C.; GALYEAN, M. L. Effects of

Saccharomyces cerevisiae subspecies boulardii CNCM I-1079 on feed intake by healthy beef cattle treated with florfenicol and on health and performance of newly received beef heifers. Journal of Animal Science, v. 85, n. 5, p. 1264-1273, 2007.

KREHBIEL, C. R.; RUST, S. R.; ZHANG, G.; GILLILAND, S. E. Bacterial direct-fed microbials in ruminant diets : Performance response and mode of action. Journal of Animal Science, v. 81, n. November, p. 120 132, 2003.

NAGARAJA, T. G.; TAYLOR, M. B. Susceptibil ity and resistance of rumin al bacteria to an timi crob ial feed add iti ves. Applied and Environmental Microbiology, Washin gton, v . 53 , n . 7 , p. 1620-1625, 1987. LITHERLAND, N. Oklahoma Dairy 
Report - A dairy nutrition newsletter. Oklahoma State University Issue 2, vol. $1,2007$.

PENHA, L. A. C.; PARDO, P. E.; KRONKA, S. N.; REIS, L. S. L. S.; OBA, E.; BREMER-NETO, H. Effects of probiotic supplementation on liveweight gain and serum cortisol concentration in cattle. Veterinary Record, v. 168, n. 20, p. 20-22, 2011.

PETERSON, R. E.; KLOPFENSTEIN, T. J.; ERICKSON, G. E.; FOLMER, J.; HINKLEY, S.; MOXLEY, R. A.; SMITH, D. R. Effect of Lactobacillus acidophilus strain NP51 on Escherichia coil O157:H7 fecal shedding and finishing performance in beef feedlot cattle. Journal of Food Protection, v. 70, n. 2, p. 287-291, 2007.

SCOTT, M. F.; DORTON, K. L.; HENRY, D. L.; BELKNAP, C. R.; HANSON, D. L.; DEPENBUSCH, B. E. Effects of feeding a Saccharomyces cerevisiae fermentation prototype on performance, carcass characteristics, and liver abscess prevalence of beef heifers at a commercial feedlot.

Professional Animal Scientist, v. 33, n. 3, p. 320-326, 2017.

SEO, J. K.; KIM, S. W.; KIM, M. H.; UPADHAYA, S. D.; KAM, D. K.; HA, J. K. Direct-fed microbials for ruminant animals. Asian-Australasian Journal of Animal Sciences, v. 23, n. 12, p. 1657-1667, 2010.

STOVER, M. G.; WATSON, R. R.; COLLIER, R. J. Pre-and Probiotic Supplementation in Ruminant Livestock Production. Probiotics, Prebiotics, and Synbiotics: Bioactive Foods in Health Promotion, p. 938, 2016.

UYENO, Y.; SHIGEMORI, S.; SHIMOSATO, T. Effect of Probiotics/Prebiotics on Cattle Health and Productivity. Microbes and environments, v. 30, n. 2, p. 126-132, 2015.

VASCONCELOS, J. T.; ELAM, N. A.; BRASHEARS, M. M.; GALYEAN, M. L. Effects of increasing dose of live cultures of Lactobacillus acidophilus (Strain NP 51) combined with a single dose of Propionibacterium freudenreichii (Strain NP 24) on performance and carcass characteristics of finishing beef steers. Journal of Animal Science, v. 86, n. 3, p. 756762, 2008.

VIBHUTE, V. M.; SHELKE, R. R.; CHAVAN, S. D.; NAGE, S. P. Effect of probiotics supplementation on the performance of lactating crossbred cows. Veterinary World, v. 4, n. 12, p. 557-561, 2011. 